\title{
Filobacillus milensis gen. nov., sp. nov., a new halophilic spore-forming bacterium with Orn-D-Glu-type peptidoglycan
}

\author{
Heinz Schlesner, ${ }^{1}$ Paul A. Lawson, ${ }^{2}$ Matthew D. Collins, ${ }^{2}$ Norbert Weiss, ${ }^{3}$ \\ Uta Wehmeyer, ${ }^{1}$ Horst Völker ${ }^{1}$ and Michael Thomm ${ }^{1}$
}

Author for correspondence: Heinz Schlesner. Tel: +49 431880 4332. Fax: +49 4318802194. e-mail: hschlesner@ifam.uni-kiel.de

\footnotetext{
1 Institut für Allgemeine Mikrobiologie der Universität Kiel, Am Botanischen Garten 1-9, D-24118 Kiel, Germany

2 Department of Food Science and Technology, University of Reading Reading RG6 6AP, UK

3 Deutsche Sammlung von Mikroorganismen und Zellkulturen $\mathrm{GmbH}$, Mascheroder Weg 1b, D-38124 Braunschweig, Germany
}

\begin{abstract}
A spore-forming, halophilic bacterium was isolated from surface sediment located on the beach of Palaeochori Bay near to a shallow water hydrothermal vent area, Milos, Greece. The bacterium, designated SH 714', consisted of motile, strictly aerobic rods which contained an Orn-D-Glu type murein and a G+C content of $35 \mathrm{~mol} \%$. Thin sections showed a cell wall typical for Grampositive bacteria; the peptidoglycan layer, however, was very thin. The Gramreaction of the organism was negative. Comparative 16S rRNA gene sequencing demonstrated that the isolate represents a new line of descent within the spore-forming rods branching at the periphery of the rRNA group 1 Bacillus (Bacillus sensu stricto). The nearest phylogenetic neighbours of the unknown bacterium were Bacillus haloalkaliphilus, Marinococcus albus and Halobacillus species. Based on phylogenetic and phenotypic evidence it is proposed that the unknown bacterium be classified as Filobacillus milensis

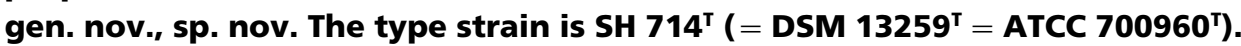

Keywords: Filobacillus milensis, taxonomy, phylogeny, hydrothermal vent, 16S rRNA

\section{INTRODUCTION}

Palaeochori Bay on the south-east coast of the island of Milos, Greece, is characterized by a variety of shallow water hydrothermal vents found along tectonic fault lines (Dando et al., 1995). Although the environmental systems and microbial ecology of deepsea hydrothermal vents has been investigated in some detail (Humphris et al., 1995), the microbiota of shallow water hydrothermal vents is much less clear. Studies on the micro-organisms from extreme environments, such as hypersaline environments, have revealed the presence of a considerable diversity of organisms, constituting both moderately halophilic as well as halotolerant bacteria (Ventosa et al., 1998; Oren, 1999). The application of molecular genetic [e.g. 16S rRNA gene sequencing, amplified rDNA restriction analysis (ARDRA)] and improved phenotypic approaches (e.g. miniaturized biochemical testing, protein profiling) has aided the recognition of a number of new genera and species which exhibit

The GenBank accession numbers for the 16S rRNA gene sequences of SH $714^{\top}$ and Bacillus haloalkaliphilus are AJ23842 and AJ23841, respectively. halophilic and/or halotolerant properties [e.g. Bacillus dipsosauri (Lawson et al., 1996), Bacillus marismortui (Arahal et al., 1999), Bacillus salexigens (Garabito et al., 1997), Gracilibacillus (Wainø et al., 1999), Halobacillus (Spring et al., 1996) and Virgibacillus (Heyndrickx et al., 1998)]. During the course of an investigation of the aerobic heterotrophic bacterial biota of a shallow water hydrothermal vent system we have used 16S rRNA gene sequencing to phylogenetically characterize a hitherto unknown Bacilluslike bacterium. Based on phylogenetic and phenotypic evidence, it is proposed that the unknown bacterium be classified as Filobacillus milensis gen. nov., sp. nov.

\section{METHODS}

Bacterial strains. Bacillus haloalkaliphilus (DSM 5271 ${ }^{\mathrm{T}}$ ) was a donation from D. Fritze, DSMZ (Deutsche Sammlung von Mikroorganismen und Zellkulturen, Braunschweig, Germany). Virgibacillus pantothenticus (DSM 26 ${ }^{\mathrm{T}}$ ) and Escherichia coli K-12 (DSM 498) were purchased from DSMZ.

Media. M13 $(3 \times)$ : peptone, $0.75 \mathrm{~g}$; yeast extract, $0.75 \mathrm{~g}$; glucose, $0 \cdot 75 \mathrm{~g}$; Hutner's basal salts medium (HBM, CohenBazire et al., 1957), $20 \mathrm{ml}$; vitamin solution no. 6 (Staley, 
1968), $10 \mathrm{ml} ; 0 \cdot 1 \mathrm{M}$ Tris $/ \mathrm{HCl}$ buffer, $\mathrm{pH} 7.5$ for liquid medium, $\mathrm{pH} 8.5$ for agar solid medium, $50 \mathrm{ml}$; artificial sea water (ASW; Lyman \& Fleming, 1940), $250 \mathrm{ml}$; distilled water to 11 . For solid medium $18 \mathrm{~g}$ agar was added.

M36M: Casein after Hammarsten (Merck), $1 \mathrm{~g}$; yeast extract, $0.25 \mathrm{~g}$; gelatin, $1.0 \mathrm{~g}$; HBM, $20 \mathrm{ml}$; vitamin solution no. 6, $10 \mathrm{ml}$; ASW (3.5-fold concentrated), $970 \mathrm{ml}$. ASW was modified by addition of the following salts $\left(1^{-1}\right): \mathrm{MnCl}_{2}$, $0.4 \mathrm{~g} ; \mathrm{Na}_{2} \mathrm{SiO}_{3}, 0.57 \mathrm{~g} ;\left(\mathrm{NH}_{4}\right)_{2} \mathrm{SO}_{4}, 0.26 \mathrm{~g}$.

Sampling, enrichment and isolation. Strain $\mathrm{SH} 714^{\mathrm{T}}$ was isolated from the beach of Palaeochori Bay near a shallow water hydrothermal vent area, Milos, Greece. At a hot spot (surface temperature $62^{\circ} \mathrm{C}$ ) in front of the water line a hole of about $10 \mathrm{~cm}$ depth was dug and from the accumulating interstitial water a sample was taken with a $20 \mathrm{ml}$ syringe. For enrichment of halophilic or halotolerant bacteria $100 \mu \mathrm{l}$ of sample was transferred to $50 \mathrm{ml}$ medium M36M. After incubation at $37^{\circ} \mathrm{C}$ for 3 weeks, subcultures were performed over various solid media. Upcoming colonies on medium $\mathrm{M} 13(3 \times)$ supplemented with $10 \%(\mathrm{w} / \mathrm{v}) \mathrm{NaCl}$ [designated $\mathrm{M} 13(3 \times)+10 \% \mathrm{NaCl}$ ] were purified by several successive subcultures from a single colony.

Culture conditions. Strain SH $714^{\mathrm{T}}$ was cultured on $\mathrm{M} 13(3 \times)+10 \% \mathrm{NaCl}$, Bacillus haloalkaliphilus on medium DSM 31 with the addition of $5 \% \mathrm{NaCl}$, Virgibacillus pantothenticus on nutrient agar plus $4 \% \mathrm{NaCl}$ and Escherichia coli on nutrient agar (DSM 1). The strains were incubated aerobically at $37^{\circ} \mathrm{C}$.

Electron microscopy. Cells were fixed by adding glutaraldehyde to the medium (final concentration $3 \%, \mathrm{w} / \mathrm{v}$ ). Fixation time was $4 \mathrm{~h}$. The prefixed cells were collected by centrifugation. The pellet was mixed with Noble Agar (Difco) at $50{ }^{\circ} \mathrm{C}$ and cut into pieces. After washing with cacodylate buffer $(0 \cdot 15 \mathrm{M}, \mathrm{pH} 7 \cdot 2$; Hayat, 1989) postfixation was done for $3 \mathrm{~h}$ in a mixture of $2 \mathrm{ml} \mathrm{OsO}$ $(4 \%)+$ ruthenium red $(0 \cdot 2 \%)+2 \mathrm{ml}$ cacodylate buffer at $5{ }^{\circ} \mathrm{C}$. Dehydration occurred in a graded series of ethanol. Embedding was done in ERL (Spurr). Sections were cut with a Reichert Ultracut E, mounted on grids and post-stained with uranyl acetate and lead citrate. Electron micrographs were taken with a Philips EM 300 on Kodak electron microscope film no. 4489. Shadow casting of air-dried cells was done with $\mathrm{Pt} / \mathrm{C}$ at an angle of $35^{\circ}$.

Gram-stain, $\mathrm{KOH}$ test, test for aminopeptidase and demonstration of flagella. For testing the Gram reaction two procedures were used: (a) the conventional 4-step Gram stain procedure and (b) the Bacto 3-step Gram stain procedure (Difco). Strain SH $714^{\mathrm{T}}$ and Bacillus haloalkaliphilus were tested after $6 \mathrm{~h}, 1,3,5,7$ and $12 \mathrm{~d}$ growth. The negative control was Escherichia coli and as a positive control Virgibacillus pantothenticus was used. The KOH test was performed according to Gregersen (1978). L-Alanine aminopeptidase was tested by using Bactident Aminopeptidase test strips (Merck). Flagella were demonstrated according to Kodaka et al. (1982).

Biochemical and physiological tests. Hydrolysis of casein, gelatin and starch was performed on solid medium $\mathrm{M} 13(3 \times)+10 \% \mathrm{NaCl}$ except that casein after Hammarsten $(2 \mathrm{~g})$, gelatin $(2 \mathrm{~g})$ and starch $(2 \mathrm{~g})$ were substituted for peptone or glucose, respectively. Hydrolysis of casein was recognized by a clear halo around positive colonies in the turbid medium. The breakdown of gelatin was visualized by flooding the Petri dish with aqueous hot saturated ammonia sulphate. The denatured gelatin caused turbidity of the medium leaving a clear zone around protease-positive colonies. Amylase activity was demonstrated by the iodine reaction. DNA hydrolysis was tested using DNase test agar with methyl green (Difco) supplemented with $5 \% \mathrm{NaCl}$. Pullulan hydrolysis was tested according to Morgan et al. (1979) with the modification that pullulan was added to the culture medium. Hydrolysis of tributyrin was tested on agarsolidified culture medium containing $1 \%$ tributyrin which was autoclaved separately. Ammonia production was determined by Nessler's reagent in modified medium $\mathrm{M} 13(3 \times)+10 \% \mathrm{NaCl}$ in which the peptone concentration was raised to $2.25 \mathrm{~g} \mathrm{l}^{-1}$ and glucose was omitted. Dissimilatory nitrate reduction was tested in medium $\mathrm{M} 13(3 \times)+10 \% \mathrm{NaCl}$ supplemented with $\mathrm{KNO}_{3}\left(1 \cdot 5 \mathrm{~g} \mathrm{l}^{-1}\right)$. The test tubes containing Durham tubes to collect gaseous nitrogen compounds were incubated anaerobically under nitrogen atmosphere. Acid formation from carbohydrate was tested in modified $\mathrm{M} 13(3 \times)+10 \% \mathrm{NaCl}$ medium in which glucose was omitted and $0.05 \%$ gelatin and $0.1 \%$ carbohydrate were added. The tubes were incubated aerobically. Fermentation of glucose was tested in the same medium in test tubes containing Durham tubes and under a nitrogen atmosphere. Antibiotic susceptibility was tested on solid $\mathrm{M} 13+10 \% \mathrm{NaCl}$ with bioDiscs (bioMérieux) which were dispensed with a Sensi Disc-Dispenser (Becton Dickinson). The following tests were performed as described by Smibert \& Krieg (1994): catalase activity, phosphatase activity (method 1), oxidase activity, hippurate hydrolysis (method 2), aesculin hydrolysis and Voges-Proskauer reaction.

Peptidoglycan analysis. Preparation of cell walls and determination of peptidoglycan structure were carried out by the methods described by Schleifer \& Kandler (1972) with the modification that TLC on cellulose sheets was used instead of paper chromatography. Briefly, $1 \mathrm{mg}$ freeze-dried cell walls were hydrolysed in $0.2 \mathrm{ml} 4 \mathrm{M} \mathrm{HCl}$ at $100{ }^{\circ} \mathrm{C}$ for $16 \mathrm{~h}$ (total hydrolysate) and $45 \mathrm{~min}$ (partial hydrolysate), respectively. Diamino acids were identified from total hydrolysate by one-dimensional chromatography in a methanol/pyridine/water/10 M HCl (320:40:70:10, by vol.) solvent system. Amino acids and peptides from partial hydrolysate were identified after two-dimensional chromatography, as outlined by Schleifer \& Kandler (1972). The resulting fingerprints were compared with those from known peptidoglycan structures.

DNA base composition determination. DNA was extracted from cells following the procedure of Marmur (1961) and analysis of the $\mathrm{G}+\mathrm{C}$ content of DNA by HPLC was performed according to Mesbah et al. (1989).

Phylogenetic analysis. The $16 \mathrm{~S}$ rRNA genes of SH $714^{\mathrm{T}}$ and Bacillus haloalkaliphilus were amplified by PCR and directly sequenced using a Taq Dye Deoxy Terminator Cycle Sequencing kit (Applied Biosystems) and an automatic DNA sequencer (model 373A; Applied Biosystems). The closest known relatives of the newly sequenced organisms were determined by performing sequence database searches. These sequences and those of other known related strains were retrieved from the GenBank or Ribosomal Database Project (RDP) libraries and aligned with the newly determined sequence using the program PILEUP (Devereux et al., 1984). The alignment was manually adjusted and approximately 100 bases at the $5^{\prime}$ end of the rRNA were omitted from further analyses because of alignment ambiguities and a continuous stretch of 1320 bases was used for distance matrix analysis. A tree was constructed by the neighbour-joining method (using the Kimura 2-correction parameter) and the stability of the groupings was estimated 
by bootstrap analysis (500 replications) using the programs contained within the same package (Felsenstein, 1989).

\section{RESULTS AND DISCUSSION}

The unknown isolate consisted of motile rod-shaped cells with dimensions $0 \cdot 3-0 \cdot 5 \times 3-7 \mu \mathrm{m}$. The cells were motile by one laterally inserted flagellum as demon- strated by the procedure of Kodaka et al. (1982; results not shown) and by electron microscopy (Fig. 1a). The organism produced spherical polar endospores with swollen sporangia. The Gram reaction of very young cultures (6 h) and older ones (up to $12 \mathrm{~d}$ old) was negative by both procedures. Ultrathin sections of the cells showed the typical Gram-positive cell wall, i.e. without an outer membrane, with a rather thin
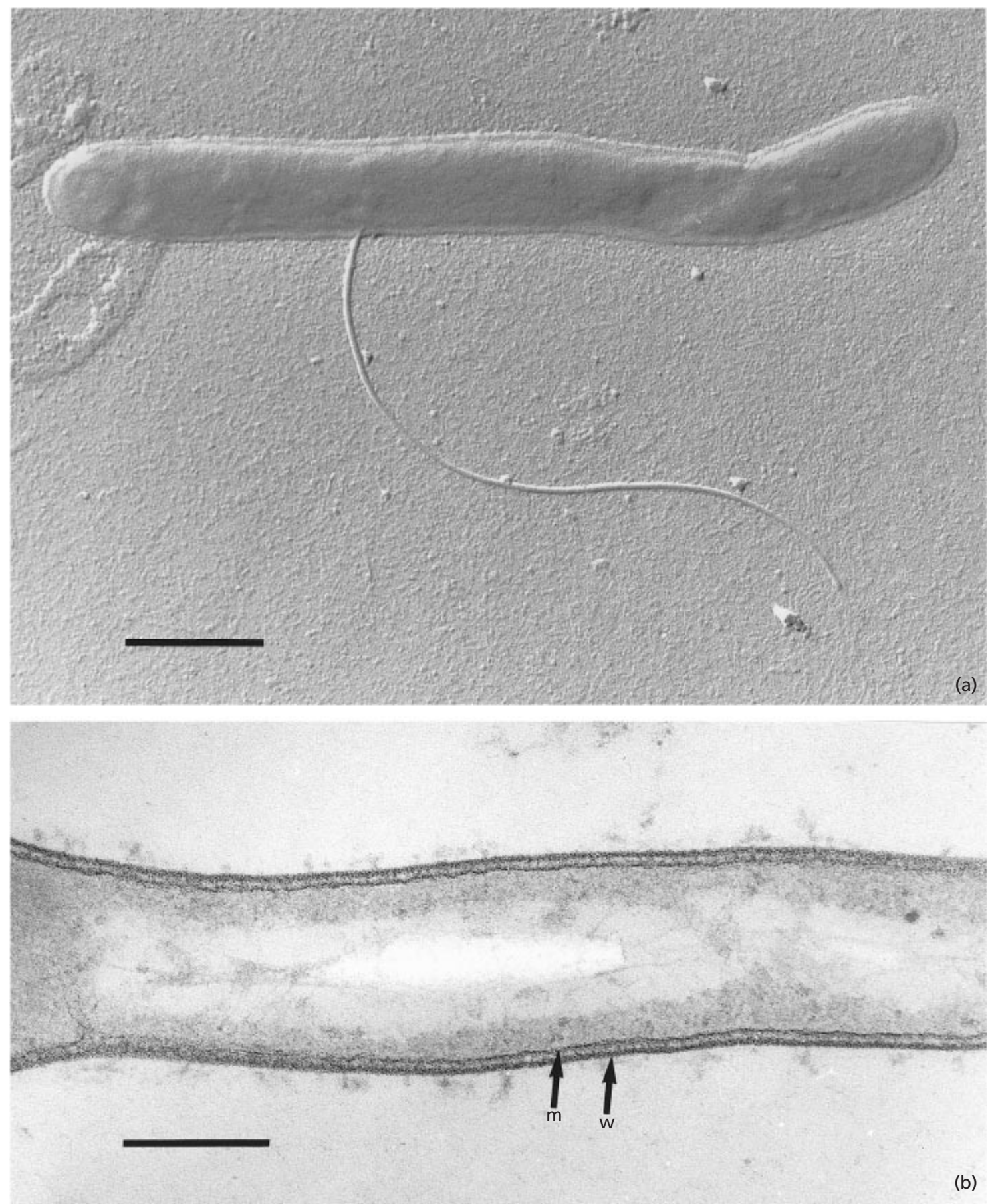

Fig. 1. Electron micrographs of Filobacillus milensis $\mathrm{SH} 714^{\top}$. (a) $\mathrm{A} \mathrm{Pt/C-shaded} \mathrm{cell} \mathrm{with} \mathrm{flagellum.} \mathrm{Bar,} 0.5 \mu \mathrm{m}$. (b) Ultrathin section showing cytoplasmic membrane $(\mathrm{m})$ and cell wall $(\mathrm{w})$. Bar $0.2 \mu \mathrm{m}$. 
peptidoglycan layer $(\sim 10 \mathrm{~nm}$, Fig. $1 \mathrm{~b})$ (the width of the peptidoglycan layer for most Gram-positive bacteria is reported to be between 30 and $80 \mathrm{~nm}$; Trüper \& Schleifer, 1992). This might explain the unusual Gram reaction. Both the $\mathrm{KOH}$ test and the test for L-alanine aminopeptidase showed a negative reaction as reported for Gram-positive bacteria (Gregersen, 1978; Cerny, 1978). Similar observations have been reported earlier: Campbell \& Postgate (1965) described a negative Gram stain for Desulfotomaculum nigrificans (ex Clostridium nigrificans) while Sleytr et al. (1969) found the fine structure of the cell wall typical for Gram-positive bacteria. 16S rRNA analyses clearly indicated that Desulfotomaculum species clustered in the Gram-positive bacteria group with low $\mathrm{G}+\mathrm{C}$ content (Devereux et al., 1984; Fowler et al., 1986). The phototrophic Heliobacteriaceae, grouping phylogenetically near Desulfotomaculum, also give a negative Gram stain (Madigan, 1992). The Gram reaction of the closest relative of strain SH $714^{\mathrm{T}}$, Bacillus haloalkaliphilus, was also negative, though it has been described as a Gram-positive bacterium. Fritze (1996), however, did not report on the Gram-stain but concluded the Gram-positive character of the cell wall from the negative result of the $\mathrm{KOH}$ test.

Strain SH $714^{\mathrm{T}}$ was mesophilic, catalase-positive and oxidase-negative. The organism grew in a range from 2 to $23 \% \mathrm{NaCl}$ (optimum $8-14 \% \mathrm{NaCl}$ ) and had a $\mathrm{pH}$ range of 6.5-8.9 with an optimum of 7.3-7.8. Using conventional tests the organism failed to produce acid from D-glucose, D-galactose, D-fructose, D-lactose, maltose, mannitol, sucrose, trehalose or D-xylose. The isolate hydrolysed DNA, hippurate and tributyrin but not casein, aesculin, gelatin, pullulan or starch. The organism did not reduce nitrate to nitrite. The VogesProskauer test was negative. L-Alanine-aminopeptidase and phosphatase were not produced. Analysis of the cell wall of the unknown isolate revealed the presence of an L-Orn-D-Glu type murein (variation A4 $\beta$; nomenclature of Schleifer \& Kandler, 1972).

The 16S rRNA gene of the unknown isolate was amplified by PCR and sequenced to ascertain its phylogenetic position. A near complete 16S rRNA gene sequence was generated $(>1400$ bases) and searches of GenBank and RDP databases revealed the unknown organism was most closely related to Bacillus haloalkaliphilus ( $96 \%$ sequence similarity). Other $\mathrm{Ba}$ cillus species exhibiting relatively high sequence relatedness with the halophilic isolate were members of rRNA group 1 (Ash et al., 1991) and group 6 (Nielsen et al., 1994).

The treeing analysis confirmed Bacillus haloalkaliphilus was the nearest known phylogenetic relative of the unidentified isolate (Fig. 2). Bootstrap resampling showed the association between the halophilic rod and Bacillus haloalkaliphilus was highly significant (bootstrap value $100 \%$ for 500 tree replications). Several other halophilic or halotolerant taxa (e.g. Halobacillus species, Virgibacillus species, Gracilibacillus species, Bacillus marismortui, Salibacillus salexigens and
Marinococcus albus) were more remotely related and displayed significantly greater sequence divergence values (approx. 6-8\%) with the unknown rod.

A tree constructed by the neighbour-joining method, depicting the phylogenetic relationships of the unknown isolate, is shown in Fig. 2 and demonstrates that the unknown bacterium represents a new subline within the spore-forming rods branching at the periphery of rRNA group 1 Bacillus (Ash et al., 1991). It is evident from the phylogenetic analysis that the unidentified rod-shaped bacterium recovered from a sandy beach in Greece represents a new subline within the aerobic/facultative anaerobic Gram-positive endospore-forming taxa. Both sequence divergence and treeing topology considerations demonstrate the nearest phylogenetic relative of the unknown bacterium corresponds to Bacillus haloalkaliphilus. This latter species is an obligately alkaliphilic and extremely halotolerant organism originally isolated from alkaline, highly saline mud (Fritze, 1996). The unknown isolate and Bacillus haloalkaliphilus formed a distinct cluster branching at the periphery of rRNA group 1 Bacillus (Ash et al., 1991). Some other halophilic taxa also branch proximal to the base of rRNA group 1 Bacillus but were quite separate from the unknown rod-shaped bacterium and Bacillus haloalkaliphilus. Alkaliphilic organisms of rRNA group 6 (Nielsen et al., 1994) form a separate group and were only remotely related to the unknown isolate. The association of the unknown rod and Bacillus haloalkaliphilus was unexpected as these taxa possess quite different cell wall murein structures. Bacillus haloalkaliphilus, in common with the great majority of endospore-forming rod-shaped bacteria, possess a directly cross-linked murein based on m-Dpm (variation A $1 \gamma$ ). By contrast, the unknown spore-forming isolate contained a murein type based on L-ornithine (type L-Orn-D-Glu). This murein type is somewhat unusual and within the context of this study this particular wall type is found only in Bacillus cohnii, Bacillus insolitus and Halobacillus species. The former two species are members of rRNA groups 1 and 2, respectively, whereas Halobacillus species form a distinct subcluster closely associated with the non-sporeforming Marinococcus albus (Fig. 2). It is pertinent to note that in addition to cell wall murein structures, the unknown rod-shaped isolate differs markedly from Bacillus haloalkaliphilus in its inability to grow at high $\mathrm{pH}$. The $\mathrm{pH}$ ranged from 6.5 to 8.9 with an optimum of 7.3-7.8. By contrast, Bacillus haloalkaliphilus is alkaliphilic, failing to grow at neutral $\mathrm{pH}$ and grows at $\mathrm{pH}$ 9.7 (Fritze, 1996). In addition, the unknown isolate differs from Bacillus haloalkaliphilus in hydrolysing DNA, but not aesculin or gelatin, and by its negative oxidase reaction. Bacillus haloalkaliphilus is DNasenegative, hydrolyses gelatin and is oxidase-positive.

It is evident from the phylogenetic analysis that the described spore-forming, rod-shaped isolate cannot be assigned to the genus Bacillus, nor to any of the other currently described spore-forming genera. Although 


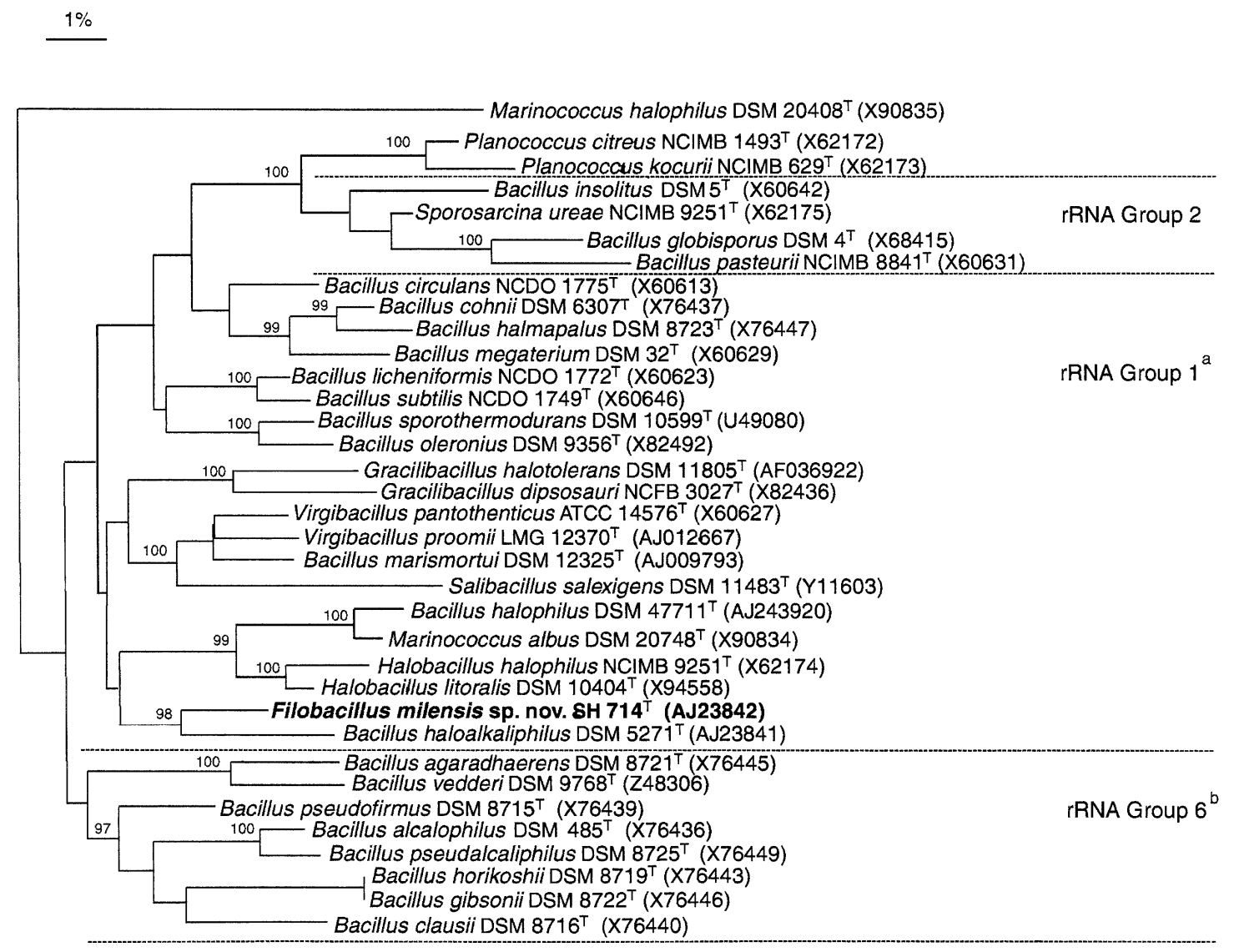

Fig. 2. Tree showing the phylogenetic inter-relationships of Filobacillus milensis sp. nov. and its closest relatives. The tree constructed using the neighbour-joining method was based on a comparison of approximately 1320 nt. Bootstrap values, expressed as a percentage of 500 replications, are given at the branching points. a, rRNA group 1 according to Ash et al. (1991); ${ }^{b}$, rRNA group 6 according to Nielsen et al. (1994). Bar, $1 \%$ sequence divergence.

Table 1 Characteristics useful in differentiating Filobacillus milensis from some other physiologically or morphologically similar species

Data from Arahal et al. (1999), Fritze (1996), Garabito et al. (1997), Heyndrickx et al. (1998), Lawson et al. (1996), Spring et al. (1996), Wainø et al. (1999) and this study (*). Abbreviations: E, ellipsoidal; S, spherical; C, central; ST, subterminal; T, terminal; NA, not applicable; ND, no data.

\begin{tabular}{|c|c|c|c|c|c|c|c|c|c|c|c|c|c|c|}
\hline \multirow[t]{2}{*}{ Characteristic } & \multirow{2}{*}{$\begin{array}{l}\text { Spore } \\
\text { shape }\end{array}$} & \multirow{2}{*}{$\begin{array}{l}\text { Sporangium } \\
\text { position }\end{array}$} & \multirow{2}{*}{$\begin{array}{c}\text { Gram } \\
\text { reaction }\end{array}$} & \multirow{2}{*}{$\begin{array}{l}\text { Growth in } \\
\text { the presence } \\
\text { of } 20 \% \mathrm{NaCl}\end{array}$} & \multirow{2}{*}{$\begin{array}{c}\text { Growth at } \\
50^{\circ} \mathrm{C}\end{array}$} & \multirow{2}{*}{$\begin{array}{l}\text { Murein } \\
\text { type }\end{array}$} & \multicolumn{3}{|c|}{ Acid produced from: } & \multicolumn{3}{|c|}{ Hydrolysis of: } & \multirow{2}{*}{$\begin{array}{l}\text { Nitrate } \\
\text { reduction }\end{array}$} & \multirow{2}{*}{$\begin{array}{c}\mathbf{G}+\mathbf{C} \text { content } \\
\quad(\mathrm{mol} \%)\end{array}$} \\
\hline & & & & & & & Glucose & Trehalose & Xylose & Casein & Gelatin & Starch & & \\
\hline Filobacillus milosensis* & $\mathrm{S}$ & $\mathrm{T}$ & - & + & - & Orn-D-Glu & - & - & - & - & - & - & + & 35 \\
\hline Bacillus haloalkaliphilus & $\mathrm{S}$ & $\mathrm{T}$ & $-^{*}$ & + & - & m-Dpm & - & - & - & - & + & - & + & $37-38$ \\
\hline Bacillus halophilus & $\mathrm{E}$ & $\mathrm{C}$ & + & + & + & m-Dpm & + & + & + & - & - & - & - & $51 \cdot 5$ \\
\hline Marinococcus albus & - & NA & + & + & ND & m-Dpm & - & - & - & - & - & - & + & $44 \cdot 9$ \\
\hline Halobacillus halophilus & $\mathrm{S}$ & $\mathrm{C} / \mathrm{T}$ & + & + & - & Orn-D-Asp & - & - & - & + & + & + & - & $40 \cdot 1-40 \cdot 9$ \\
\hline Halobacillus litoralis & $\mathrm{E} / \mathrm{S}$ & $\mathrm{C} / \mathrm{ST}$ & + & + & - & Orn-D-Asp & + & + & + & - & + & - & - & 42 \\
\hline Gracilibacillus halotolerans & $\mathrm{E}$ & $\mathrm{T}$ & + & + & + & m-Dpm & + & + & + & - & + & + & + & 38 \\
\hline Gracilibacillus dipsosauri & $\mathrm{S}$ & $\mathrm{T}$ & + & - & + & m-Dpm & + & + & + & - & + & + & + & $39 \cdot 4$ \\
\hline Salibacillus salexigens & $\mathrm{E}$ & $\mathrm{C} / \mathrm{ST}$ & + & + & - & m-Dpm & + & - & - & + & + & - & - & $39 \cdot 5$ \\
\hline Bacillus marismortui & $\mathrm{E}$ & $\mathrm{T} / \mathrm{ST}$ & + & + & + & m-Dpm & + & - & - & + & + & - & + & $40 \cdot 7$ \\
\hline Virgibacillus pantothenticus & $\mathrm{E} / \mathrm{S}$ & $\mathrm{T}$ & + & - & + & m-Dpm & + & + & - & + & + & + & + & $36 \cdot 9$ \\
\hline Bacillus agaradhaerens & $\mathrm{E}$ & ST & + & - & - & $\mathrm{ND}$ & + & + & - & + & + & + & + & $39 \cdot 3-39 \cdot 5$ \\
\hline Bacillus pseudofirmus & $\mathrm{E}$ & ST & + & - & - & ND & + & + & - & + & + & + & - & $39-40 \cdot 8$ \\
\hline
\end{tabular}


the unknown isolate clustered with Bacillus haloalkaliphilus, we consider the marked physiological differences of these organisms in concert with their distinct cell wall murein structures preclude their assignment to a single genus. Therefore, based on phylogenetic and phenotypic evidence it is proposed that the unknown bacterium, from beach sediment be classified in a new genus Filobacillus, as Filobacillus milensis sp. nov. The type strain of Filobacillus milensis is SH $714^{\mathrm{T}}\left(=\mathrm{DSM} 13259^{\mathrm{T}}=\mathrm{ATCC} 700960^{\mathrm{T}}\right)$. Tests, which serve to distinguish Filobacillus milensis from its nearest phylogenetic relatives and some phenotypically similar organisms, are shown in Table 1.

\section{Description of Filobacillus gen. nov.}

Filobacillus (Fi.lo.ba.cil'lus. L. masc. n. filum thread; L. n. bacillus rod; M.L. n. Filobacillus a thread-like rod).

Cells are $0 \cdot 3-0 \cdot 4 \times 3-7 \mu \mathrm{m}$ and stain Gram-negative, but the cell wall is of the Gram-positive type. Motile. Spores are spherical and are located terminally. Sporangium swollen. Catalase-positive and oxidase-negative. Does not grow (or grows very poorly) in media without the addition of $\mathrm{NaCl}$. Mesophilic, alkalitolerant and halophilic. Acid is not produced from Dglucose. Voges-Proskauer-negative. Nitrate is not reduced to nitrite. $\mathrm{KOH}$ test negative. The cell wall contains an L-Orn-D-Glu type murein (variation A4 $\beta$ ). The $\mathrm{G}+\mathrm{C}$ content of the DNA is $35 \mathrm{~mol} \%$. The type species is Filobacillus milensis. As determined by $16 \mathrm{~S}$ rRNA gene sequence analysis, the genus Filobacillus is located on the periphery of rRNA group 1 Bacillus and is phylogenetically most closely related to Bacillus haloalkaliphilus.

\section{Description of Filobacillus milensis sp. nov.}

Filobacillus milensis (mi.len'sis. M.L. gen. n. milensis from the island Milos, Greece, where the organism was isolated).

Cells are rods, $0 \cdot 3-0 \cdot 4 \times 3-7 \mu \mathrm{m}$. Cells are motile, one flagellum is laterally inserted. On M13(3×) $+10 \%$ $\mathrm{NaCl}$ colonies are white, smooth and $1-2 \mathrm{~mm}$ diameter. Does not grow (or grows very poorly) in media without $\mathrm{NaCl}$. The $\mathrm{NaCl}$ range is approximately $2-23 \%$ with an optimum of $8-14 \%$. Mesophilic. Temperature optimum is from 33 to $38^{\circ} \mathrm{C}$., maximum growth temperature is between 40 and $42{ }^{\circ} \mathrm{C}$. The $\mathrm{pH}$ range of growth is $6.5-8.9$ with an optimum between $7 \cdot 3$ and $7 \cdot 8$. Hippurate, DNA and tributyrin are hydrolysed. Aesculin, casein, gelatin, starch and pullulan are not hydrolysed. Acid is not produced from D-glucose, D-galactose, D-fructose, maltose, mannitol, sucrose, trehalose or D-xylose. L-Alanine aminopeptidase- and phosphatase-negative. Sensitive to ampicillin, chloramphenicol, streptomycin and tetracycline, but not to kanamycin. Other characters as for the genus description. The $\mathrm{G}+\mathrm{C}$ content of the DNA is $35 \mathrm{~mol} \%$. Type strain is $\mathrm{SH} 714^{\mathrm{T}}\left(=\mathrm{DSM} 13259^{\mathrm{T}}=\right.$
ATCC $700960^{\mathrm{T}}$ ), isolated from a beach sediment from Palaeochori Bay, Milos, Greece. Characteristics useful in differentiating Filobacillus milensis species from some other physiologically or morphologically similar species are shown in Table 1.

\section{ACKNOWLEDGEMENTS}

We gratefully acknowledge the project co-ordinator Paul Dando and Soteris Varnavas for organizing the field trips. Part of this study was funded by a grant from the EC (MAS3-CT95-0021) and of the Fonds der Chemischen Industrie. We thank Dagmar Fritze for donation of the type strain of Bacillus haloalkaliphilus.

\section{REFERENCES}

Arahal, D. R, Marquez, M. C, Volcani, B. E, Schleifer, K.-H. \& Ventosa, A. (1999). Bacillus marismortui sp. nov., a new moderately halophilic species from the Dead Sea. Int J Syst Bacteriol 49, 521-530.

Ash, C., Farrow, J. A. E., Wallbanks, S. \& Collins, M. D. (1991). Phylogenetic heterogeneity of the genus Bacillus revealed by comparative analysis of small-subunit-ribosomal RNA. Lett Appl Microbiol 13, 202-206.

Campbell, L. L. \& Postgate, J. R. (1965). Classification of the sporeforming sulfate-reducing bacteria. Bacteriol Rev 29, 356-363.

Cerny, G. (1978). Studies on aminopeptidase for the distinction of Gram-negative from Gram-positive bacteria. Eur $J$ Appl Microbiol Biotechnol 5, 113-122.

Cohen-Bazire, G., Sistrom, W. R. \& Stanier, R. Y. (1957). Kinetic studies of pigment synthesis by non-sulphur purple bacteria. $J$ Cell Comp Physiol 49, 25-68.

Dando, P. R, Hughes, J. A, Leahy, Y., Niven, S. J, Taylor, L. J. \& Smith, C. (1995). Venting rates from submarine hydrothermal areas around the island of Milos, Hellenic Volcanic Arc. Cont Shelf Res 15, 913-929.

Devereux, J., Haeberli, P. \& Smithies, O. (1984). A comprehensive set of sequence analysis programs for the VAX. Nucleic Acids Res 12, 387-395.

Felsenstein, J. (1989). PHYLIP - phylogeny inference package (version 3.2). Cladistics 5, 164-166.

Fowler, V. J, Widdel, F., Pfennig, N., Woese, C. R. \& Stackebrandt, E. (1986). Phylogenetic relationships of sulfate- and sulfurreducing eubacteria. Syst Appl Microbiol 8, 32-41.

Fritze, D. (1996). Bacillus haloalkaliphilus sp. nov. Int J Syst Bacteriol 46, 98-101.

Garabito, M. J, Arahal, D. R, Mellado, E., Marquez, M. C. \& Ventosa, A. (1997). Bacillus salexigens sp. nov., a new moderately halophilic Bacillus species. Int J Syst Bacteriol 47, 735-741.

Gregersen, T. (1978). Rapid method for distinction of Gramnegative from Gram-positive bacteria. Eur J Appl Microbiol Biotechnol 5, 123-127.

Hayat, M. A. (1989). Principles and Techniques of Electron Microscopy, 3rd edn, pp. 20-23. London: MacMillan.

Heyndrickx, M., Lebbe, L., Kersters, K., De Vos, P., Forsyth, G. \& Logan, N. A. (1998). Virgibacillus: a new genus to accommodate Bacillus pantothenticus (Proom and Knight 1950). Emended description of Virgibacillus pantothenticus. Int J Syst Bacteriol 48, 99-106. 
Humphris, S. E., Zierenberg, R. A., Mullineaux, L. S. \& Thomson, R. E. (editors) (1995). Seafloor Hydrothermal Systems. Physical, Biological and Geological Interactions. American Geophysical Union Monograph, vol. 91. Washington, DC: American Geophysical Union.

Kodaka, H., Armfield, A. Y, Lombard, G. L. \& Dowell, V. R., Jr (1982). Practical procedure for demonstrating bacterial flagella, J Clin Microbiol 16, 948-952.

Lawson, P. A, Deutch, C. E. \& Collins, M. D. (1996). Phylogenetic characterization of a novel salt-tolerant Bacillus species: description of Bacillus dipsosauri sp. nov. J Appl Bacteriol 81, 109-112.

Lyman, J. \& Fleming, R. H. (1940). Composition of sea water. $J$ Mar Res (Sears Foundation) 3, 134-146.

Madigan, M. T. (1992). The family Heliobacteriaceae. In The Prokaryotes, 2nd edn, pp. 1981-1992. Edited by A. Balows, H. G. Trüper, M. Dworkin, W. Harder \& K.-H. Schleifer. New York: Springer.

Marmur, J. (1961). A procedure for the isolation of deoxyribonucleic acid from microorganisms. J Mol Biol 3, 208-218.

Mesbah, M., Premachandran, U. \& Whitman, W. B. (1989). Precise measurement of the $\mathrm{G}+\mathrm{C}$ content of deoxyribonucleic acid by high-performance liquid chromatography. Int $J$ Syst Bacteriol 39, 159-167.

Morgan, F. J, Adams, K. R. \& Priest, F. G. (1979). A cultural method for the detection of pullulan-degrading enzymes in bacteria and its application to the genus Bacillus. $J$ Appl Bacteriol 46, 291-294.

Nielsen, P., Rainey, F. A, Outtrup, H., Priest, F. G. \& Fritze, D. (1994). Comparative 16S rDNA sequence analysis of some alkaliphilic bacilli and the establishment of a sixth rRNA group within the genus Bacillus. FEMS Microbiol Lett 117, 61-66.
Oren, A. (1999). Bioenergetic aspects of halophilism. Microbiol Mol Biol Rev 63, 334-348.

Schleifer, K.-H. \& Kandler, O. (1972). Peptidoglycan types of bacterial cells walls and their taxonomic implications. Bacteriol Rev 36, 407-477.

Sleytr, U., Adam, H. \& Klaushofer, H. (1969). Die Feinstruktur der Zellwand und Cytoplamamembran von Clostridium nigrificans, dargestellt mit Hilfe der Gefrierätz- und Ultradünnschnittechnik. Arch Mikrobiol 66, 40-58.

Smibert, R. M. \& Krieg, N. R. (1994). Phenotypic characterisation. In Methods for General and Molecular Bacteriology, pp. 607-654. Edited by P. Gerhardt, R. G. E. Murray, W. A. Wood \& N. R. Krieg. Washington, DC: American Society for Microbiology.

Spring, S., Ludwig, W., Marquez, M. C, Ventosa, A. \& Schleifer, K.-H. (1996). Halobacillus gen. nov., with descriptions of Halobacillus litoralis sp. nov. and Halobacillus trueperi sp. nov., and transfer of Sporosarcina halophila to Halobacillus halophilus comb. nov. Int J Syst Bacteriol 46, 492-496.

Staley, J. T. (1968). Prosthecomicrobium and Ancalomicrobium: new prosthecate freshwater bacteria. J Bacteriol 95, 1921-1942.

Trüper, H. G. \& Schleifer, K.-H. (1992). Prokaryote characterization and identification. In The Prokaryotes, 2nd edn, pp. 126-148. Edited by A. Balows, H. G. Trüper, M. Dworkin, W. Harder \& K.-H. Schleifer. New York: Springer.

Ventosa, A., Nieto, J. J. \& Oren, A. (1998). Biology of moderately halophilic aerobic bacteria. Microbiol Mol Biol Rev 62, 504-544.

Wainø, M., Tindall, B. J, Schumann, P. \& Ingvorsen, K. (1999). Gracilibacillus gen. nov., with description of Gracilibacillus halotolerans gen. nov., sp. nov.; transfer of Bacillus dipsosauri to Gracilibacillus dipsosauri comb. nov., and Bacillus salexigens to the genus Salibacillus gen. nov., as Salibacillus salexigens comb. nov. Int J Syst Bacteriol 49, 821-831. 